\title{
ISOLATION AND CHARACTERIZATION OF METHANOTROPHIC BACTERIA FROM RICE FIELDS
}

\author{
IMAN RUSMANA $^{1}$ and ALINA AKHDIYA ${ }^{2}$ \\ ${ }^{1}$ Departement of Biology, Bogor Agricultural University, Jl. Agathis, Darmaga, Bogor, Indonesia \\ ${ }^{2}$ Indonesian Research Center for Agricultural Biotechnology and Genetic Resources Research and \\ Development, \\ Agency for Agricultural Research and Development, Department of Agriculture, Jl. Tentara Pelajar, \\ Cimanggu, Bogor, Indonesia
}

\begin{abstract}
Methane is a greenhouse gas capable of depleting the ozone layer. Rice fields are significant sources of atmospheric methane. The application of chemical fertilizer in rice fields increases the methane emission. Methanotrophic bacteria has a unique ability as it can utilize methane as a source of carbon and energy. This research was able to isolate and characterize successfully the methanotrophic bacteria from rice fields in Bogor and Sukabumi, in West Java, Indonesia. Methane oxidation was determined through Gas Chromatography and it shows that all isolates performed methane oxidation activity. The highest methane oxidation activity was performed by BGM 9 isolate. And the DNA amplification of BGM 9 genome was performed by a single band of mmoX in the size of $500 \mathrm{bp}$ and three bands of pmoA in the size of 1000, 750 and 500 bp respectively.
\end{abstract}

Key words: Methanotrophic bacteria, methane oxydation, methane monooxygenase, rice field.

\section{INTRODUCTION}

Rice fields In Indonesia are the backbone of rice production as well as a source of methane $\left(\mathrm{CH}_{4}\right)$ emission to the atmosphere. Methane is a greenhouse gas and has potency to deplete ozone layer. The contribution of methane in the atmosphere is approximated to $15-20 \%$ of the total greenhouse gas effect and its concentration in the atmosphere is increasing by approximately $1 \%$ per year (Mossier 1998).

It has been estimated that the methane production in the rice fields is about $575 \mathrm{Tg}$ year $^{-1}$ (Hanson \& Hanson 1996). Chemical fertilization in the rice fields increases methane emission. Application of ammonium sulphate fertilizer, as much as $140 \mathrm{~kg}$

*Coresponding authors : rusmana@yahoo.com 
$\mathrm{ha}^{-1}$ can increase methane emission. Setyanto et. al (1999) reported that emission of methane by application of ammonium sulphate fertilizer was $164-175 \mathrm{~kg} \mathrm{CH}_{4} \mathrm{ha}^{-1}$. Indonesia is the third biggest contributor of methane emission from rice fields after China and India, it is estimated $7.08 \%$ of the total world of methane emission from rice fields (Sass et al. 2000).

Measurements of methane emission in rice fields indicates that methane was oxidized in oxidation layer of soil sediment by mathanotrophic bacteria (Conrad \& Rothfus 1991). Methane oxidation was also found in the rhizosphere area (Whalen 2005). Methane oxidation activity in rice fields was up to $80 \%$ of methane produced by methanogenic archaebacteria (Conrad \& Rothfus 1991).

Methanotrophic bacteria has a unique ability as it can utilize methane as a source of carbon and energy. There are three groups of methanotrophic bacteria; type I, type II, and type X methanotrophs. The genera included in type I are Methylomonas, Methylobacter, type II methanotrophs are Methylosinus and Methylosystis, and type X methanotroph is Methylococcus capsulatus (Hanson \& Hanson 1996). Several methanotrophic bacteria of type II (four species of Methylosinus) and type X (Methylococcus capsulatus) were able to degrade TCE (trichloroethylene). Methanotrophic bacteria can also degrade methyl bromide and methyl fluoride. Mixed cultures of methanotrophic bacteria could degrade 2- and 4-chloro-biphenyl and 4-hydrroxy-2-chlorobiphenyl. The type II and type X methanotrophs have also ability to fix $\mathrm{N}_{2}$ (Hanson \& Hanson 1996).

Potential methanotrophic bacteria have great application purposes for environmental friendly and sustainable agriculture system. They have the abilities to reduce methane emission to the atmosphere, to degrade halogenated aliphatic compounds in the polluted soils and groundwater, and to fix $\mathrm{N}_{2}$. However, information about the activity and diversity of these bacteria from Indonesian rice fields is very limited. Therefore, this research project was conducted to determine the activities and diversity of these bacteria from Indonesian rice fields using microbiological and molecular techniques, so that the results and information can be used to support the achievement of environmental friendly and sustainable agricultural system program of rice fields in Indonesia.

\section{MATERIALS AND METHOD}

\section{Sample Collection}

Sediments and water samples of rice fields were collected using sediment core from several areas in Bogor and Sukabumi, West Java, Indonesia.

\section{Isolation of methanotrophic bacteria}

Isolation of methanotrophic bacteria was conducted using enrichment technique in NMS (Nitrate Minral Salts) media (Hanson 1998). One ml of both upper layer of sediment and water was inoculated into $50 \mathrm{ml} \mathrm{NMS}$ medium in $100 \mathrm{ml}$ bottles capped with butyl rubber septum. The bottle headspace will be filled up with $50 \%$ of methane and $50 \%$ of air. Incubation was held on shaker for 5-6 days in room temperature. 
Enrichment of type II methanotrophic bacteria that have ability to fix $\mathrm{N}_{2}$ will be carried out in the same media without nitrate but with gas composition in the headspace such as of $20 \%$ air, $5 \% \mathrm{CO}_{2}, 25 \% \mathrm{~N}_{2}$ and $50 \%$ methane (Hanson 1998).

Isolates were purified by using a streak plate technique with NMS agar, containing $100 \mathrm{mg} / 1$ cycloheximide dan $10 \mathrm{mg} / \mathrm{l}$ amphoterisin B (Hanson 1998). The plates were incubated for 5-6 days in an anaerobic jar with similar gas composition as mentioned above. The pure isolates was characterized based on cell morphology and physiological assays.

\section{Determination of Methane Monooxygenase Activity}

Qualitative Determination of MMO enzymes activity was determined using a colony plate assay based on naphthalene oxidation stained with orto-dianisidine and the activity of MMO was measured using Gas Chomatograph (Shimadzu 17A; Shimadzu, Kyoto, Japan) (Hanson 1998).

\section{Genomic DNA Isolation of Methanotrophic bacteria}

Genomic DNA of selected isolates was extracted using alkaline lyses methods (Sambrook et al. 1989). The extracted DNA was used as a template for amplification of mmoX gene using Polimerise Chain Reaction (PCR) technique. PCR machine (Perkin elmer PCR GeneAmp, USA).

\section{Amplification of pmoA and mmoX genes}

Specific primers of A189F (GGNGACTGGGACTTCTGG) and mb661 (CCGGMGCAACGTCYTTACC) were used in amplifying pmoA gene (Bourne et al 2001). While specific primers of mmoXA (ACCAAGGARCART'TCAAG) and mmoXB (TGGCACTCRTARCGCTC) were used in amplifying mmoX gene (Auman et al. 2000). PCR amplification reactions were performed in $25 \mu \mathrm{l}$ reaction mixtures. Individual reagents and their concentrations were as follows: 1X PCR Buffer, $1.5 \mathrm{mM}$ $\mathrm{MgCl}_{2}, 1.5$ units of $\mathrm{taq}$ DNA polymerase, $20 \mu \mathrm{g}$ of bovine serum albumin, $200 \mu \mathrm{mol}$ of dNTP, 20 pmol each primer, and $1 \mu \mathrm{l}$ of template DNA. Taq pol was added after the initial denaturalization step at $96^{\circ} \mathrm{C}$ for 5 minutes, followed by 30 cycles at $94^{\circ} \mathrm{C}$ for 1 minute, $56^{\circ} \mathrm{C}$ for 1 minute, and $72^{\circ} \mathrm{C}$ for 1 minute. A final extension period of 5 minutes at $72^{\circ} \mathrm{C}$ was observed (Bourne et al. 2001).

\section{RESULTS AND DISCUSSION}

\section{Isolates of Methanotrophic Bacteria}

Isolation of methanotrophic bacteria from 7 samples of rice field in Bogor and Sukabumi provided 37 isolates, i.e. 15 isolates were isolated from the rice fields in Bogor and 22 isolates were isolated from the rice fields in Sukabumi (Table 1). Colony morphology of the isolates on NMS media were of different colors such as white, yellow. pink, and orange. The growth rate and colony development on NMS agar also varied. It took up to 14 days to develop a colony with diameter of $2 \mathrm{~mm}$. 
Table 1. Bacterial Isolates isolated from rice fields in Bogor and Sukabumi

\begin{tabular}{|c|c|c|c|}
\hline Origin of Sampel & Sampel Code & Number of isolate & Isolate Code \\
\hline \multirow[t]{2}{*}{ Bogor } & BG1 & 10 & $\begin{array}{l}\text { BGM 1, BGM 2, BGM 3, } \\
\text { BGM 4, BGM 5, BGM 6, } \\
\text { BGM 7, BGM 8, BGM 9, } \\
\text { BGM } 10\end{array}$ \\
\hline & BG2 & 5 & $\begin{array}{l}\text { BGM 11, BGM 12, BGM 13, } \\
\text { BGM 14, BGM } 15\end{array}$ \\
\hline \multirow[t]{5}{*}{ Sukabumi } & SK1 & 3 & SKM 1, SKM 2, SKM 18 \\
\hline & SK2 & 3 & SKM 3, SKM 4, SKM 19 \\
\hline & SK3 & 7 & $\begin{array}{l}\text { SKM 5, SKM 6, SKM 7, SKM } \\
\text { 8, SKM 9, SKM 10, SKM } 20\end{array}$ \\
\hline & SK4 & 5 & $\begin{array}{l}\text { SKM 11, SKM 12, SKM 13, } \\
\text { SKM 17, SKM } 21\end{array}$ \\
\hline & SK5 & 4 & $\begin{array}{l}\text { SKM 14, SKM 15, SKM 16, } \\
\text { SKM } 22\end{array}$ \\
\hline
\end{tabular}

Methanotrophic bacteria have different pigments, some of them had yellow and brown pigments (Hanson \& Hanson 1996), others did not have or they have white pigment, pink (Eller \& Frenzel 2001) and reddish orange (Holt et al. 1994). This methanotropic bacteria was slow growing and the optimum growth on NMS media was 14 days of incubation.

\section{Qualitative Determination of sMMO Activity}

Qualitative assay of activity sMMO found that BGM 8 isolate performed activity of sMMO (Fig. 1). Positive result of the assay was indicated by the change in color from white/cream into violet after treatment using naphtalena and o-dianisidin. Brusseau et al. (1990) reported that type II methanotrophs having sMMO could convert napthalene into naphtol. This reaction is an indicator that merthanotrophic bacteria could degrade thrichloroethilene.
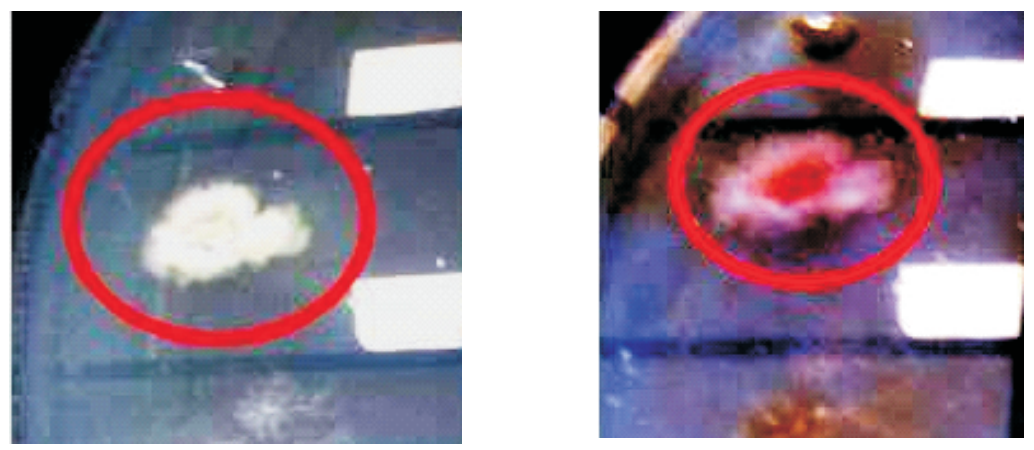

Figure 1. Positive results of sMMO assay performed by BGM 8 isolate (a) before assay (b) after assay 
Copper $\left(\mathrm{Cu}^{2+}\right)$ could regulate MMO biosynthesis in methanotrophs. The bacteria will produce pMMO if they were grown in media containing high $\mathrm{Cu}^{2}(\mathrm{Zahn} \&$ Dispirito 1996). pMMO enzyme was found in all methanotrophic bacteria (Hanson \& Hanson 1996). But, in low $\mathrm{Cu}^{2+}$ condition, some methanotrophic bacteria such as Methylosinus trichosporium OB3b (Lipscomb 1994) and Methylomonas (Shigematsu et al. 1999) will produce sMMO. Graham et al. (1992) reported that concentration of 1-2 $\mu \mathrm{M} \mathrm{Cu}{ }^{2+}$ could inhibit synthesis of sMMO in $M$. trichosporium OB3b, M. methanica (ATCC 35067) and Type II methanotrophs DG1 species.

\section{Activity of Methane Oxydation}

Methane analysis results showed that all isolates have ability to oxidize methane (unpublished data). The best isolate was chosen based on methane oxydation activity and bacterial growth on NMS agar. Six isolates i.e. BGM 1, BGM 2, BGM 3, BGM 9, BGM 12, dan SKM 14) were selected for further experiment including. More detail analysis of methane oxydation activity carried out showed that BGM 9 has the highest activity of methane oxydation, followed by SKM 14 (Fig. 2).

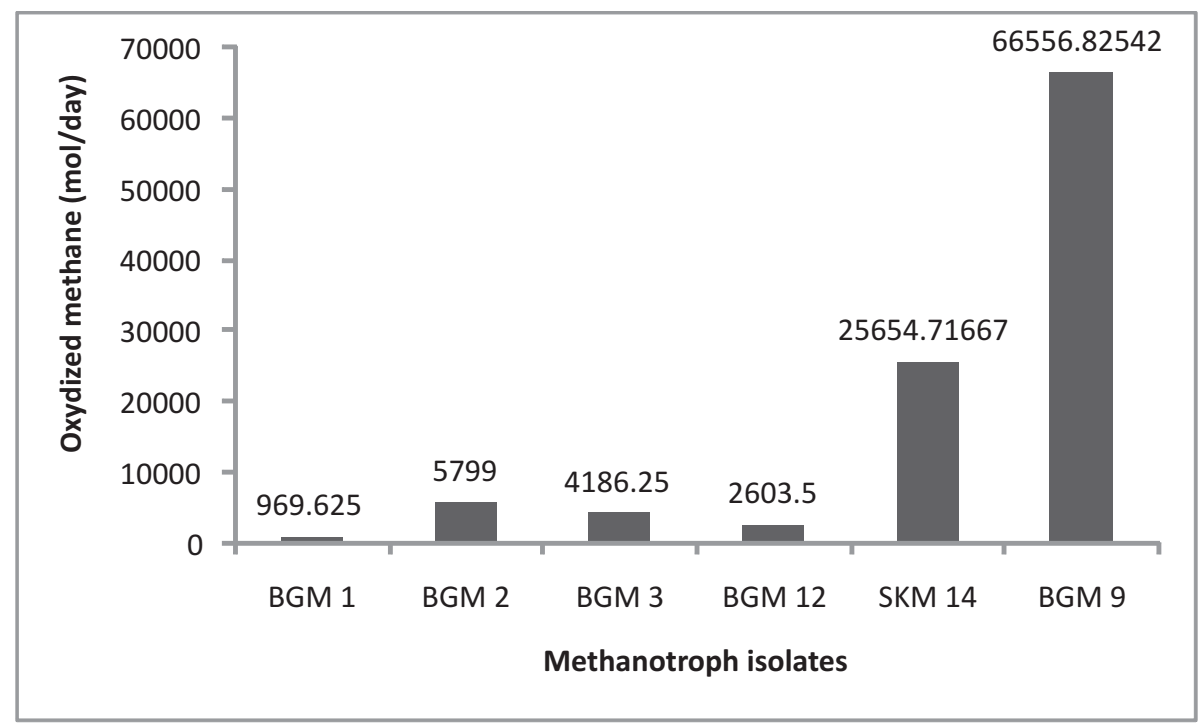

Figure 2. Methane oxydation activity of six methanotroph isolates . 


\section{Phenotive and Physiological Characteristics of BGM 9 and SKM 14 isolates}

Based on microscopic observation, bacterial cells of BGM 9 and SKM 14 isolates were Gram negative, rod, and motile. Results of physiological assay showed that the isolates have positive raction on $\mathrm{H}_{2} \mathrm{~S}$ production and urease assays. But they showed negative result for oxydase, indole and glucose assays.

Phenotive characterization of BGM 9 and SKM 14 isolates indicated that the isolates are closely related with methanotrophic bacteria type II. Holt et al. (1994) in Bergey's Manual of Determinative Bacteriology grouped this bacteria into Gram negative eubacteria. Methylobacterium was described as a bacterium with rod cell, gram negative, motile, slow growing, pink until orange in colour of the colony, optimum growth at $25-30^{\circ} \mathrm{C}$, and aerobic obligate. Characteristics of SKM 14 isolate were very similar with Methylobacterium.

\section{Amplification of pmoA dan mmoX Genes}

Amplification of $p m o \mathrm{~A}$ dan mmoX genes from selected isolates showed that mmoX of BGM 9 was performed on a single band of amplified DNA in the size of $500 \mathrm{bp}$. This band size was tipically for mmoX gene amplification band (Fig. 2). Auman et al. (2000) reported that the size of mmoX gene PCR product using mmoXA and mmoXB specific primers was $510 \mathrm{bp}$. This results confirmed that BGM 9 isolate has sMMO enzyme. However aplification of pmoA was performed on three bands of amplified DNA in the size of 1000, 750 and 500 bp respectively (Fig. 3). These results indicated that the isolates have $p m o$ gene, however this pmo gene PCR product still need to be investigated more detail to determine which band is the spesific band for $p m o$ A gene.

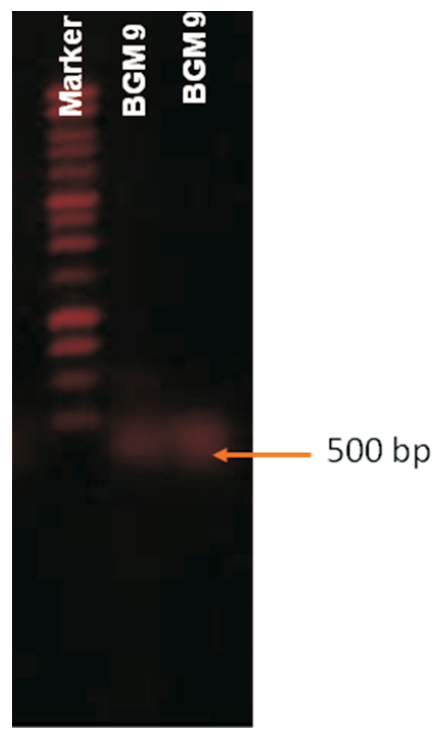

Figure 2. Aplification results BGM 9 using mmoX specific primer of BGM 9 DNA genome. 


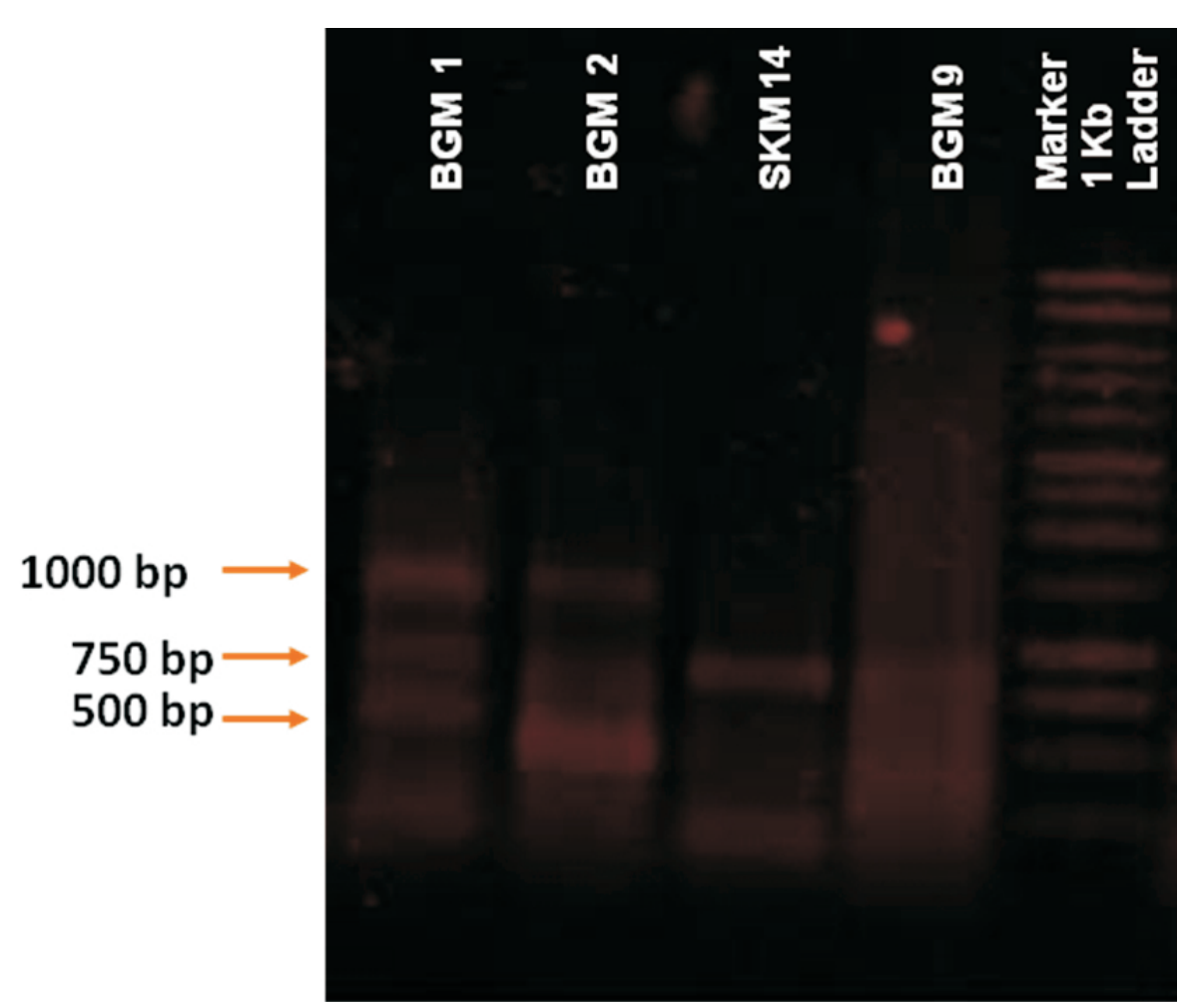

Figure 3. Aplification results using pmoA specific primer of BGM9, SKM14, BGM2 and BGM1 DNA genome.

\section{CONCLUSION}

As many as 37 isolates of methanotrophic bacteria were isolated from rice fields in Bogor and Sukabumi, West Java. The highest activity of methane oxydation was performed by BGM 9 isolate. This isolate also had the characteristics activity of sMMO enzymes. BGM 9 was performed on a single band of amplified mmoX DNA in the size of $500 \mathrm{bp}$ and aplification of $p m o \mathrm{~A}$ was performed on three bands of amplified DNA in the size of 1000,750 and 500 bp respectively. More detail molecular study including identification based on $16 \mathrm{~S}$ rRNA sequences should be conducted to determine the diversity of methanotrophic bacteria in Indonesian rice fields.

\section{ACKNOWLEDGEMENT}

This study was supported by a research grant of DIPA SEAMEO BIOTROP in 2008. 


\section{REFERENCES}

Brusseau G.A., Tsien H.C., Hanson R.S. and L.P. Wackett. 1990. Optimization of trichloroethylene oxidation by methanotrophs and the use of a colorimetric assay to detect soluble methane monooxygenase activity. Biodegradation, 1:19-29.

Bourne D.G., McDonald I.R. and J.C. Murrell. 2001. Comparison of pmoA PCR primer sets as tools for investigating methanotroph diversity in three Danish soils. Applied and Environmental Microbiology, 67:3802-3809.

Conrad R. and F. Rothfus. 1991. Methane oxidation in the soil surface layer of a flooded rice field and the effect of ammonium. Biology and Fertility of Soils. 12: 28-32.

Eller G. and P. Frenzel. 2001. Changes in activity and community structure of methane-oxidizing bacteria over the growth period of rice. Applied and Environmental Microbiology, 67 (6): 2395-2403.

Graham D.W., Korich D.G., Leblanc R.P., Sinclair N.A. and R.G. Arnold. 1992. Applications of a Colorimetric Plate Assay for Soluble Methane Monooxygenase Activity. Applied and Environmental Microbiology, 58(7): 2231-2236.

Hanson R.S. 1998. Ecology of methylotrophic bacteria. In: Burlage R.S., Atlas R., Stahl D., Geesey G. and G. Dayler (eds). Techniques in Microbial Ecology: 137-162. Oxford University Press. Oxford.

Hanson R.S. and T.E. Hanson. 1996. Methanotrophic bacteria. Microbiological Reviews, 60: 439-471.

Holt J.G., Krieg N.R., Sneath P.H.A., Staley J.T. and S.T. Williams. 1994. Bergey's Manual of Determinative Bacteriology. $9^{\text {th }}$ Edition. Lippincott William \& Wilkins: a Wolter Kluwer Co.

Lipscomb J.D. 1994. Biochemistry of soluble methane monooxygenase. Annual Review of Microbiology, 48: 371399.

Sambrook J.E., Fritsch E. and T. Maniatis. 1989. Molecular Cloning: a Laboratory Manual. $2{ }^{\text {nd }}$ Edition. Cold Spring Harbor Laboratory Press, New York.

Setyanto P., Suharsih, Wihardjaka A. dan A.K. Makarim. 1999. Pengaruh pemberian pupuk anorganik terhadap emisi gas metan pada lahan sawah. In: Partohardjono S., Soejitno J. dan Hermanto. Menuju Sistem Produksi Padi Berwawasan Lingkungan: 36-43. Pusat Penelitian dan Pengembangan Tanaman Pangan, Bogor.

Shigematsu T., Hanada S., Eguchi M., Kamagata Y., Kanagawa T. And R. Kuran. 1999. Soluble methane monooxygenase gene clusters from trichloroethylene-degrading Methylomonas sp. strains and detection of methanotrophs during in situ bioremediation. Applied and Environmental Microbiology, 65: 51985206.

Zahn Z.A. and A.A. Dispirito. 1996. Membrane-associated methane monooxygenase from Methylococcus capsulatus (Bath). Journal of Bacteriology, 178: 10181029. 